\title{
Nutritional Contribution of Litterfall for a Surrounding Forest Area according to the Distance of a Forest Fragment
}

\author{
Costa, Thomaz Correa e Castro (Corresponding author) \\ Embrapa Milho e Sorgo, Sete Lagoas, MG, Brazil
}

Tel: 55-31-3027-1159Ｅ-mail: thomaz.costa@embrapa.br

Miranda, Gabriel Avelar

Centro Universitário de Sete Lagoas, Sete Lagoas, MG, Brazil

Received: August 12, 2014 Accepted: August 14, $2014 \quad$ Published: November 5, 2014

doi:10.5296/jee.v5i2.6560 URL: http://dx.doi.org/10.5296/jee.v5i2.6560

\begin{abstract}
Litterfall is the principal mechanism for sustaining forests ecosystems. Besides nutrient cycling and carbon sink, there are other ecosystem services related with litterfall, such as the contribution of drift litter to neighboring areas in keeping soil fertility. The goal this work was quantify the nutrients of literfall in nearby area of the forest fragment as function of distance. Nets were installed for receiving litter, starting at the edges of the forest fragment. The litterfall deposited on the edge and at distances of 5 by 5 meters from the edge was collected during three months. In order to estimate the deposition of this litter after one year, wind data, and monitoring data of deciduous inside the fragment were used. The results showed supply of nutrients of literfall until 20 meters distant from the fragment. And when we are considering the export of nutrients at harvest of maize in crop with low use of inputs the replacement of $\mathrm{Ca}$ can reach $45 \%$ at distance of 20 meters, showing the relevance of nutrient input in nearby areas of forest fragments.
\end{abstract}

Keywords: Ecosystem services, Modeling, Crop, Maize 


\section{Introduction}

The nutrients absorbed by plants return to the soil by litterfall (twigs, branches, flowers and fruits of plants and remains of animal and dead roots), and rain water, which make up the ecosystem. The litter is biomass with all these components deposited on the ground. The formation of this layer is the primary mechanism for maintaining soil fertility as a source of organic matter and support terrestrial ecosystems, releasing nutrients by biogeochemical and physical processes (Menezes et al., 2010), serving as a habitat for micro, meso and macrofauna that act in this process, and retaining and slowly releasing rain water to the inner layers of the soil, besides contributing to the stabilization of erosion (Andrade et al., 2003).

This assembly establishes physical quality and biotic soil activity that control the dynamics and decomposition of nutrients (Harmon et al., 1999). The amount of plant material deposited from forest ecosystems forming the litterfall is expressive, and reaches tonnes per hectare per year (Costa et al., 2014; Giacomo et al., 2012; Gomes et al., 2010; Silva et al., 2007; Vital et al., 2004; Figueiredo Filho et al., 2003). The rate of litterfall is considered all the material deposited on the soil surface of a forest in a given period, which can be measured by deposition in collectors of pre-set sizes per unit time (Poggiani and Schumacher, 2000).

In the case of semideciduous forest, a typology conditioned by tropical climate seasonality, with a period of intense rains and another with severe drought, the litter deposition is defined by the stock of water in the soil (König et al., 2002). This typology of the Atlantic Forest also occurs as enclaves in the Cerrado. When associated with wavy and strongly wavy reliefs, it is usually left in environmental reserves on the property (Legal Reserve and Permanent Preservation Areas), with adjacency to small plots of cultivated land.

The functionality of forest ecosystems is increasingly present in environmental conservation policies and in payment for ecosystem services, they contribute to the regeneration of degraded areas in their surroundings through seed dispersal, they offer habitats for pollinators and natural enemies of pests and of disease vectors (Losey and Vaughan, 2006; Marco Jr. and Rabbit, 2004), cycle nutrients, store water, offer food (Zhang and Swintow, 2009), protect fauna and flora, bind carbon and contribute to buffering the local climate.

In 1997, a study calculated the value of environmental services of the planet between US\$ 16 and US\$ 34 trillion per year. The biological control accounted for US\$ 121 billion and pollination services accounted for US\$ 117 billion (Costanza et al., 1997). These are first ideas joint with water issues when we are thinks in environments services. And if appear some research with reference to the crops and forests most likely will have focus of the impact of crop on forest. It is the case of Duncan et al. (2008) that analysed the impact of fertilization of crops into nearby forest fragments.

In this work, we researched an unusual focus, the possibility of forest fragments of the surrounding areas to help to the maintenance of soil fertility, with deposition of plant material and releasing of nutrients provided by derives from the litterfall. Therefore, we tested this possibility in order to estimate the contribution of the input of litter from a fragment of semideciduous forest in a surrounding area, aiming at a quantification of this ecosystem 
service.

\section{Materials and Methods}

The study was conducted in an area of $1.03 \mathrm{ha}$, adjacent to a fragment of semideciduous forest, at the experimental farm of Embrapa Maize and Sorghum in Sete Lagoas - MG, with coordinates $44^{\circ} 09^{\prime} 33$ "O; 19²6'02 "S. The profile analysis indicates the class Inceptic Eutrustox (Costa et al., 2004), with slopes ranging from $5^{\circ}$ to $20^{\circ}$ and aspect predominating in $135^{\circ}$, southeast direction.

For receiving litterfall were installed 19 nets with mesh of $2 \times 2 \mathrm{~mm}$ and 3 meters of width with lenght between 10 and 35 meters, from the edge of the fragment, distanced 10 meters between nets (Figura 1A, B). For samples the litterfall we launched randomly a quadrant of $0.5 \times 0.5$ meters $\left(0.25 \mathrm{~m}^{2}\right)$ of 5 and 5 meters, from edge of fragment. The evaluation was performed with 14 nets, because five nets were discarded for loss of quality or because was not possible to assess the origin of the contribution due to its location in relation to forest edges.

The Thornthwaite water balance was calculated for the same periods of leaves collecting for the entire period of 2011/2012, according to Pereira's methodology (2002).

The conduction of the test was possible in the dry season, after scraping soil, desiccation maintenance, mowing and weeding. During the rainy season, the growth of exotic grasses and weeds lifted nets, precluding the maintenance and continuity of the evaluation.

The installation occurred on 13/07/11. After three months and five days, on 18/10/11, litterfall deposition was sampled with quadrant template $0.5 \times 05 \mathrm{~m}\left(0.25 \mathrm{~m}^{2}\right)$, weighed and kept in incubator at $65{ }^{\circ} \mathrm{C}$ until stabilization, to obtain the dry weight $\left(\mathrm{g} / \mathrm{m}^{2}\right)$ (Figure $\left.1 \mathrm{C}\right)$.

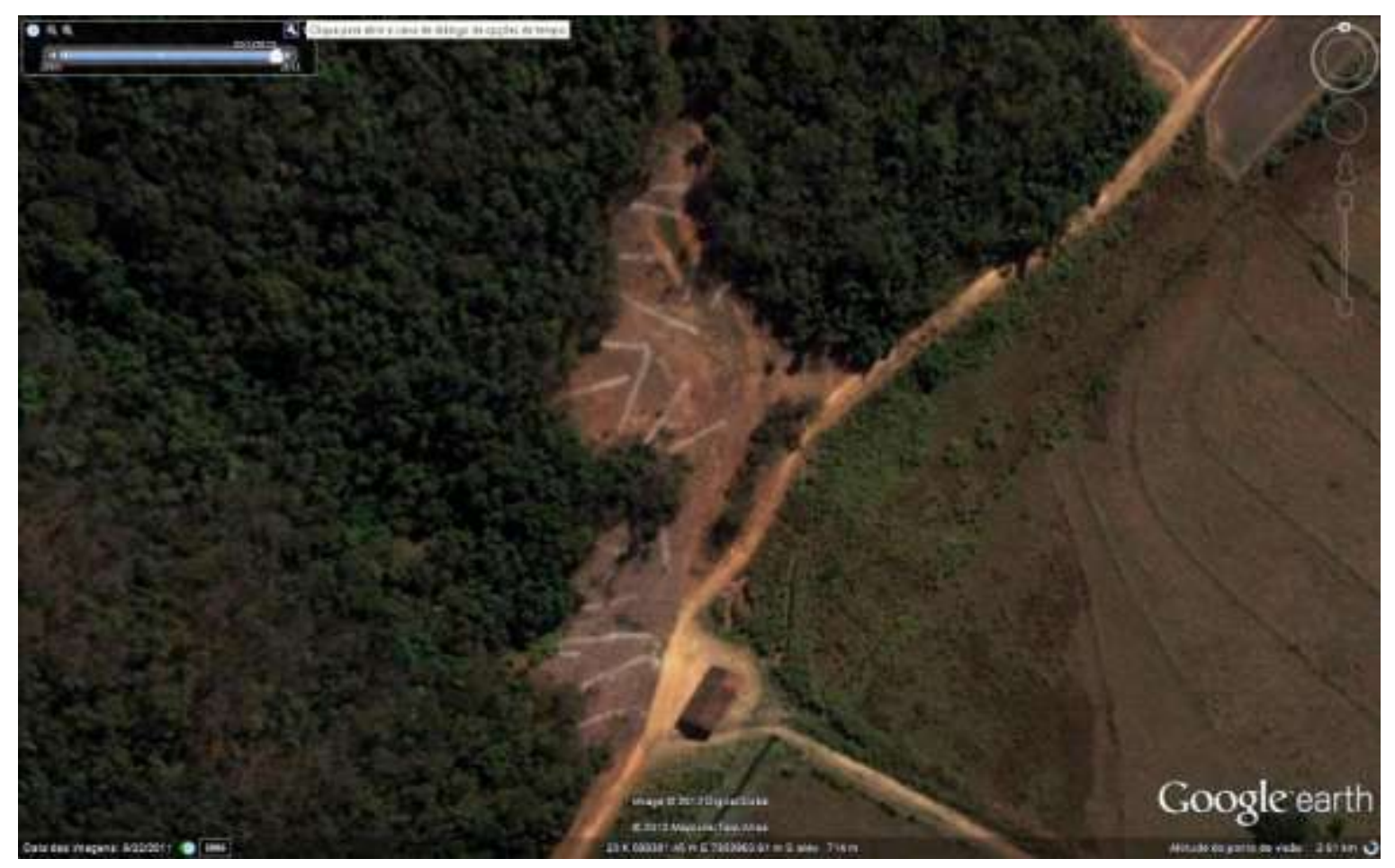






(B)
(A)

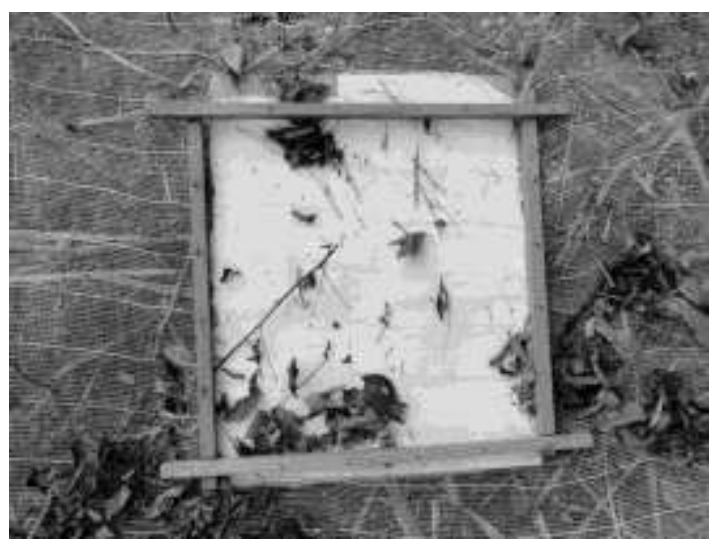

(C)

Figure 1. Distribution of nets in the adjacent area of forest at Embrapa Maize and Sorghum Farm and way of collection. (A) Orbital view (Ikonos Image/Google Earth), (B) Net detail, (C) Quadrant of $0.5 \times 0.5 \mathrm{~m}$ randomly sampled in the edge, and distances of 5, 10, 15, 20, 25, 30,35 meters from the edge of the fragment to litter collection

Inside the fragment, the monitoring of litter deposition was performed from 15/07/2011 to $15 / 07 / 2012$, through 10 nets deployed in two plots of $20 \times 20 \mathrm{~m}$. In this period, the leaves of material that formed litter were collected and weighed monthly, ground and mixed for foliar analysis of macro $(\mathrm{N}, \mathrm{P}, \mathrm{K}, \mathrm{Ca}, \mathrm{Mg})$ and micronutrients $(\mathrm{Zn}, \mathrm{Fe}, \mathrm{Mn}, \mathrm{Cu})$.

In order to estimate the deposition of litter in relation to the distance of the fragment in the periods in which material was not collected the following variables were used: speed $(\mathrm{m} / \mathrm{s})$ and direction (N, NE, E, SE, S, SW, W, NW, C-calm) of wind, collected at times 12, 18, $24 \mathrm{~h}$ in Universal Time Coordinate (UTC) of the National Institute of Meteorology (INMET) Weather Station, in Sete Lagoas, Minas Gerais, $6 \mathrm{~km}$ distant from the study area. The lack of wind data in January and February 2012, due to a defect in anemometer, was filled with the 2011 data.

The estimate of the amount of litter deposited in the adjacent area in 2011/2012 (366 days) depending on the distance of fragment, using data collected by the nets in the surrounding area (95 days), and data collected in the forest interior (366 days) was obtained by the following procedure: six frequency tables were generated, three for wind speed $(\mathrm{m} / \mathrm{s})$, and three for direction and wind way, considering the UTC times, 12, 18, 24h, and periods of monitoring of litter deposition. The winds that do not derived litter in the surrounding area (E, $\mathrm{SE}, \mathrm{S}$ ) and calm days (C) were treated as void in the analysis.

The monitoring periods were (Day of period from 01/01/11 to 31/12/12): 15/07/11 (Day of period = 196), 15/08/11 (227), 13/09/11 (256), 18/10/11 (284), 16/11/11 (320), 14/12/11 (348), 16/01/12 (381), 14/02/12 (410) 15 / 03/12 (440), 15/04/12 (471), 14/05/12 (500), 15/06/12 (532), 15/07/12 (562).

The estimate of the material which formed litter by the edge distance was obtained as follows: 
for the first three tables a factor was generated by period ( Fp), that correspond the weighted average by wind speed $\left(\mathrm{v}_{\mathrm{i}}\right)$, which indicates a greater or lesser influence on drift, multiplied by the frequency $\left(f_{i}\right)$, divided by the total frequency $\left(f_{t}\right), F_{p}=\sum_{i=1}^{n}\left(v_{i} * f_{i}\right) / f_{t}$, being $f_{t}=\sum_{i=1}^{n} f_{i}$, and $\mathrm{n}$, wind speeds occurring in the period.

The calculation of the dry weight of the litter (d.w.) at the forest edges $(d=0 \mathrm{~m})$ for each monitoring period was obtained by:

d.W.edge_period $\left(\mathrm{g} / \mathrm{m}^{2}\right)=$

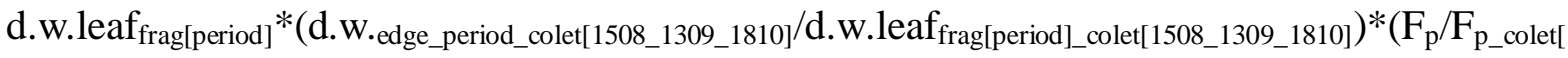
1508_1309_1810]),

Where:

d.w.edge_period $=$ dry weight of litter collected at the edge in the period;

d.w.leaf $f_{\text {frag[period] }}=$ dry weight of leaves collected in the inner forest in the period;

d.w.edge_period_colet[1508_1309_1810] $=$ dry weight of the litter at the edge for the collection period in the area adjacent to the fragment;

d.w.leaf $f_{\text {frag[period]_colet[1508_1309_1810] }}=$ dry weight of leaves collected inside the fragment in the collection period in the area adjacent to the fragment;

$F_{p}=$ factor by period; $F_{\left.p_{-} \text {colet } 1508 \_1309 \_1810\right]}=$ factor in the collection period in the area adjacent to the fragment.

For the calculation of d.w. in the distances $d=5,10,15,20,25,30,35 \mathrm{~m}$ for each period was used dry weight (d.w.) as a function of distance (d), estimated with the data collected in the period, in order to obtain the proportion of $\mathrm{d} . \mathrm{w}$. in each distance in relation to d.W.edge_period_colet[1508_1309_1810].

In the sense and direction tables, winds that drift litter to the surrounding area are N, NE, SW, $\mathrm{W}, \mathrm{NW}$. The factor per period in this case is the ratio of the sum of frequencies of valid winds (j) and the overall frequency, $F_{p}=\sum_{j=1}^{5} f_{j} / f_{t}$, being $f_{t}=\sum_{j=1}^{9} f_{j}$, including the null wind (C).

The calculation of the dry weight of the litter for the distances (d) from this step is the same for the tables of wind speed.

The value of final d.w. $\left(\mathrm{g} / \mathrm{m}^{2}\right)$ is obtained by the arithmetic average for the period between 6 tables. The sum between periods is the estimate, by distance, of drift of forming material from litter in the year 2011/2012. Through foliar analysis of macro and micronutrients of leaf litter collected in the inner forest fragment, the amount of nutrients deposited in the year 2011/2012 by distance was estimated. This estimate is possible because the nutrient content in the leaves compared to those found in the forming material litter did not vary much (König et al., 2002; Cunha et al., 1993).

The amounts of nutrients deposited in the soil were compared with data of exportation of 
nutrients for maize in two productivity levels, low and high input use.

\section{Results and Discussion}

The water balance (Figure 2) shows that with water surplus the deciduousness remains with lower rates due to senescence of leaves and the influence of wind and rain. The variation in deciduousness because of water availability was obtained by monitoring the deposition of leaves through nets within the fragment in the period of analysis (Table 1).

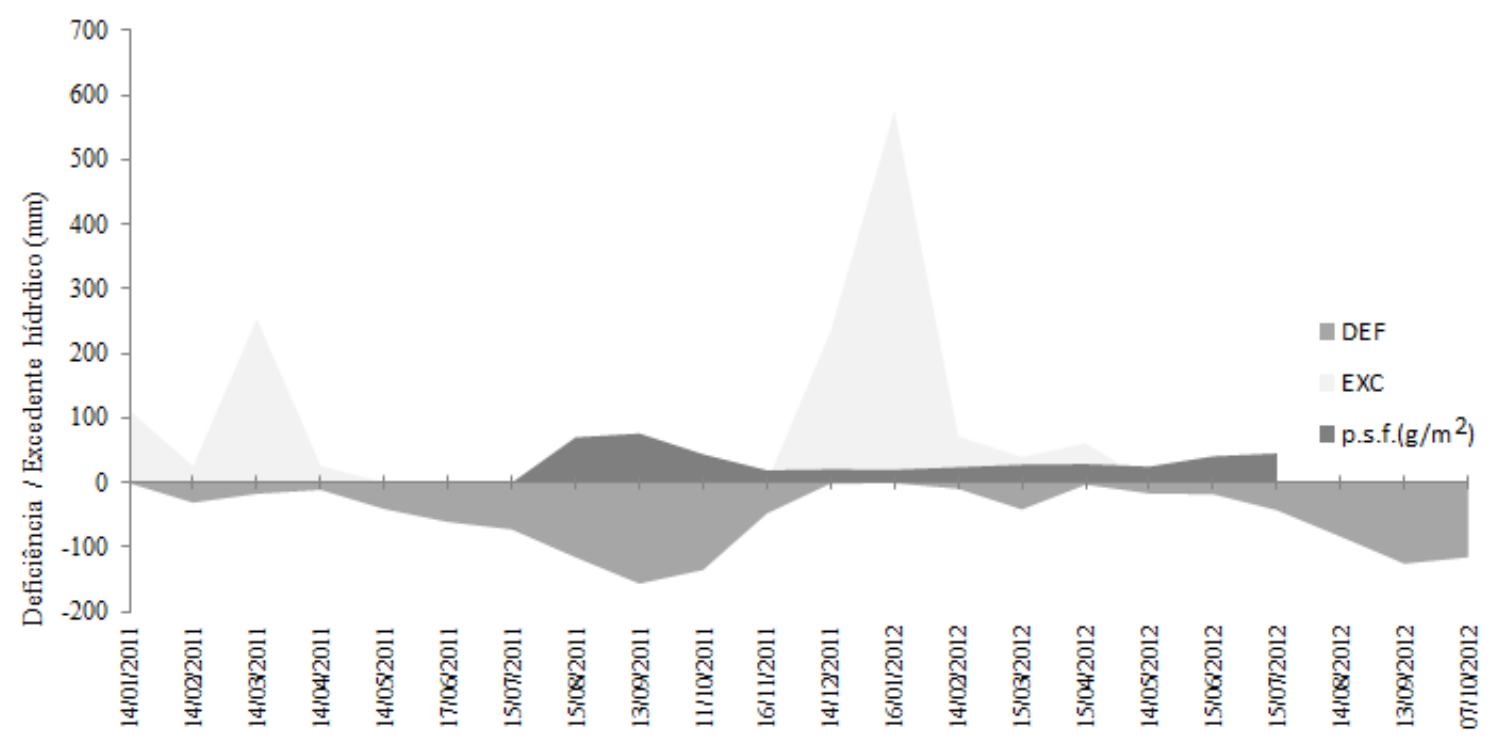

Figure 2. Monthly climatic water balance of Thornthwaite for January 2011 to October 2012 and deciduousness, in leaf dry weight $\left(\mathrm{g} / \mathrm{m}^{2}\right)$ in the period of analysis. Note: DEF (deficient) and EXC (surplus) water to each $\mathrm{CAD}=150 \mathrm{~mm}$, establishing the same accumulation period between the water balance and the litterfall

In Table 2, the data are provided for collecting litter in $\mathrm{g} / \mathrm{m}^{2}$ (twigs, branches, fruits, flowers, leaves) by distance, between 3 months and 5 days. The higher density material (twigs, branches and fruits) is deposited near the edge of the fragment, while leaves and flowers reach greater distances. The leaves in forming material of litter in seasonal forests predominate, with approximately $70 \%$ of the deposited material (Gomes et al., 2010; Vogel et al., 2007; Maman et al., 2007; König et al., 2002).

Table 1. d.w. $\left(\mathrm{g} / \mathrm{m}^{2}\right)$ weight of leaf litter gotten by 10 nets installed in two parcels of $20 \times 20$ $\mathrm{m}$ inside the fragment, distance of 80 meters from the edge (nets with no data were damaged during the collection period)

\begin{tabular}{lcccccccccccc}
\hline Period & P1R1 & P1R2 & P1R3 & P1R4 & P1R5 & P2R1 & P2R2 & P2R3 & P2R4 & P2R5 & Ave. & CV\% \\
\hline $15 / 07 / 11$ & 0 & 0 & 0 & 0 & 0 & 0 & 0 & 0 & 0 & 0 & & \\
$15 / 08 / 11$ & 61,25 & 74,00 & 77,90 & 69,72 & 62,12 & 53,37 & 97,03 & 70,63 & 45,68 & 91,26 & 70,30 & 22,58 \\
$13 / 09 / 11$ & 79,41 & 78,63 & & 89,20 & 63,46 & 74,46 & & 83,96 & 48,89 & 92,11 & 76,27 & 18,60 \\
$18 / 10 / 11$ & & 38,12 & 26,52 & 81,37 & 41,09 & 62,57 & 39,49 & 33,36 & 32,58 & 41,63 & 44,08 & 38,96 \\
$16 / 11 / 11$ & & & & 15,97 & & 18,03 & 23,10 & 24,21 & & 15,42 & 19,35 & 21,05
\end{tabular}




\begin{tabular}{|c|c|c|c|c|c|c|c|c|c|c|c|c|}
\hline $4 / 12 / 11$ & & 25,70 & 13,51 & 17,94 & 28,13 & 21,22 & 33,39 & 10,64 & 14,48 & 22,05 & 20,78 & 35,77 \\
\hline $16 / 01 / 12$ & 22,40 & 18,35 & 28,52 & 26,99 & 14,10 & 19,80 & & 08,98 & 15,10 & 27,51 & 20,19 & 33,51 \\
\hline $14 / 02 / 12$ & & 43,36 & 17,77 & 42,90 & 24,91 & 20,98 & 12,33 & 08,57 & 19,35 & 25,72 & 23,99 & 50,63 \\
\hline $15 / 03 / 12$ & 33,58 & 55,76 & 19,42 & & 37,44 & 30,41 & 14,08 & 11,51 & 21,10 & 27,96 & 27,92 & 48,78 \\
\hline $15 / 04 / 12$ & 39,87 & 45,20 & 31,74 & 32,11 & 28,99 & 27,13 & 18,02 & 16,22 & 11,34 & 39,28 & 28,99 & 38,18 \\
\hline $14 / 05 / 12$ & 22,62 & 41,85 & 25,05 & 29,45 & 26,63 & 29,58 & 13,79 & 13,08 & 21,38 & 27,78 & 25,12 & 33,09 \\
\hline $12 / 06 / 12$ & 29,32 & 22,79 & 19,73 & 34,09 & 27,99 & 67,96 & 47,16 & 41,58 & 79,08 & & 41,08 & 49,83 \\
\hline $15 / 07 / 12$ & 41,58 & 19,47 & 21,44 & 24,32 & & 81,81 & 45,46 & 75,20 & 62,72 & 38,61 & 45,62 & 50,60 \\
\hline
\end{tabular}

Table 2. Drift of litter collected from period of $13 / 07 / 11$ to $18 / 10 / 11$ by quadrant 0.5 x $0.5 \mathrm{~m}$ randomly thrown above nets in distances of 5 of 5 meters from the edge of the fragment. Note: coefficients of variation: $\mathrm{cv}=98.65 \%$ (edge), $\mathrm{cv}=96.78 \%(\mathrm{~d}=5 \mathrm{~m}), \mathrm{cv}=125 \%(\mathrm{~d}=10 \mathrm{~m})$, $\mathrm{cv}=67.47 \%(\mathrm{~d}=15 \mathrm{~m}) \mathrm{cv}=28.28 \%(\mathrm{~d}=20 \mathrm{~m})$. At distances of 25,30 and $35 \mathrm{~m}$ deposition did not occur in this period

\begin{tabular}{rrrrrr}
\hline $\begin{array}{r}\text { Collected } \\
\text { points }\end{array}$ & Dist.(m) & d.w.(g/m $\left.\mathrm{m}^{2}\right)$ & points & Dist.(m) & d.w. $\left(\mathrm{g} / \mathrm{m}^{2}\right)$ \\
\hline R2P1 & 0 & 14,16 & R12P1 & 0 & 78,00 \\
R2P2 & 5 & 74,56 & R12P2 & 5 & 30,20 \\
R5P1 & 0 & 35,60 & R12P3 & 10 & 06,32 \\
R5P2 & 5 & 50,80 & R14P1 & 0 & 0 \\
R6P1 & 0 & 69,40 & R14P2 & 5 & 17,84 \\
R6P2 & 5 & 11,04 & R15P1 & 0 & 54,96 \\
R6P3 & 10 & 05,80 & R15P2 & 5 & 0 \\
R7P1 & 0 & 114,52 & R15P3 & 10 & 04,12 \\
R7P2 & 5 & 11,48 & R15P4 & 15 & 0 \\
R8P1 & 0 & 44,80 & R15P5 & 20 & 16,44 \\
R8P2 & 5 & 4,760 & R16P1 & 0 & 95,84 \\
R8P3 & 10 & 14,12 & R16P2 & 5 & 83,16 \\
R8P4 & 15 & 08,56 & R16P3 & 10 & 33,28 \\
R8P5 & 20 & 10,96 & R16P4 & 15 & 35,36 \\
R9P1 & 0 & 265,12 & R16P5 & 20 & 0 \\
R9P2 & 5 & 20,52 & R17P1 & 0 & 85,68 \\
R10P1 & 0 & 31,76 & R17P2 & 5 & 07,76 \\
R10P2 & 5 & 04,60 & R17P3 & 10 & 0 \\
R10P3 & 10 & 03,36 & R17P4 & 15 & 15,12 \\
R11P1 & 0 & 30,80 & R18P1 & 0 & 330,72 \\
R11P2 & 5 & 11,20 & R18P2 & 5 & 24,04 \\
R11P3 & 10 & 04,44 & R18P3 & 10 & 62,44 \\
& & & R18P4 & 15 & 12,16 \\
\hline
\end{tabular}

In order to obtain a model with equation of the behavior of deposition forming material of litter, we worked with average values in Table 2 by distance. Figure 3 shows the curve 
adjusted in the logarithmic model for litter deposition $\left(\mathrm{g} / \mathrm{m}^{2}\right)$ versus the distance for the period of collection.

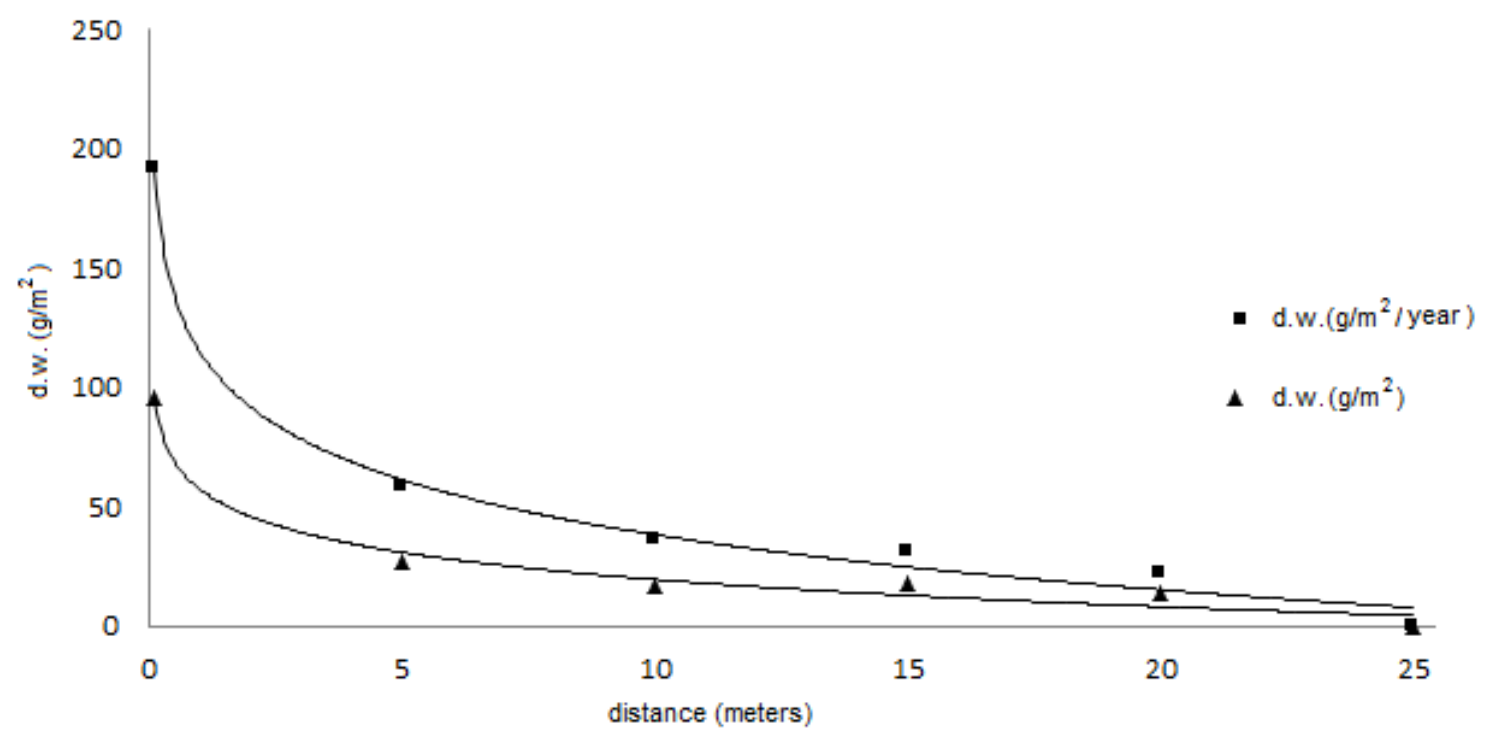

Figure 3. Dry weight average of litterfall (d.w.) as function to the distance of the fragment for the collection period, $07 / 15 / 11$ to $10 / 18 / 11\left(\mathrm{~g} / \mathrm{m}^{2}\right)$ and for the period of $07 / 15 / 11$ to $07 / 15 / 12$ $\left(\mathrm{g} / \mathrm{m}^{2} /\right.$ year $)$

The estimate of the forming material of litterfall according to the distance for the period $07 / 15 / 11$ to $07 / 15 / 12$ was obtained in the following manner, demonstrating for 12 hours (Table 3):

The factor of the period 16/11/11 (with daily measurements of winds occurring from 19/10/11 to $16 / 11 / 11)$ was:

$\mathrm{F}_{\mathrm{p}}(16 / 11 / 11)=(0+1,5+6+12+4,2+5,2+6,2+10,8+12,3+0+0+0) / 29=58,2 / 29=2,00689655$

And the factor of the reference period (15/07 to 18/10/11),

$\mathrm{F}_{\mathrm{p}}(15 / 07+13 / 09+18 / 10 / 11)=(0+3,5+11+43,5+31,5+23,4+9,3+21,6+24,6+18,4+15,3+5,7) / 95=$ $207,8 / 95=2,18736842$

The dry weight for the edge of the fragment $(d=0 \mathrm{~m})$ in the period $16 / 11 / 11$ was d.w.edge $\left(\mathrm{g} / \mathrm{m}^{2}\right)=$ d.w.leaf $f_{\text {frag }} *\left(\mathrm{~d} . \mathrm{w} \cdot \mathrm{edge}_{\text {colet }} / \mathrm{d} \cdot \mathrm{w} \cdot \mathrm{leaf}_{\text {frag_colet }}\right) *\left(\mathrm{~F}_{\mathrm{p}} / \mathrm{F}_{\mathrm{p}_{-} \text {colet }}\right)=19,35 *(96,26 / 190,64) *(2,00689$ $655 / 2,18736842)=8,96$

After the d.w.leaf of $19,35 \mathrm{~g} / \mathrm{m}^{2}$, collected within the fragment in the period 16/11/11, be transported to the d.w. on the edge, of $8,96 \mathrm{~g} / \mathrm{m}^{2}$, using the influence of the wind speed in relation the period collected, the d.w. on the edge has been transported to the distances 5,10 , $15,20 \mathrm{~m}$ using the proportions created equation d.w. $\left(\mathrm{g} / \mathrm{m}^{2}\right)=-16,44 * \ln [\mathrm{d}(\mathrm{m})]+57,455$ $\left(R^{2}=98,32 \%\right),(0,3252) d=5 / d=0 ;(0,2056) d=10 / d=0 ;(0,1357) d=15 / d=0 ;(0,0861) d=20 / d=0$.

The d.w. $\left(\mathrm{g} / \mathrm{m}^{2}\right)$ were: $2,68(\mathrm{~d}=5 \mathrm{~m}) ; 1,69(\mathrm{~d}=10) ; 1,12(\mathrm{~d}=15) ; 0,71(\mathrm{~d}=20)$, as noted in Table 3. 
In the case of direction and way, the factor of the period 16/11/11 considering the valid wind was $\mathrm{F}_{\mathrm{p}}(16 / 11 / 11)=(3+6+1+0+0) / 29=10 / 29=0,344827586$

And the factor of the reference period $(15 / 07$ to $18 / 10 / 11)$ was $\mathrm{F}_{\mathrm{p}}(15 / 07+13 / 09+18 / 10 / 11)=7+7+1+1+4 / 95=20 / 95=0,210526316$

The dry weight of the fragment edge in the period 16/11/11 was

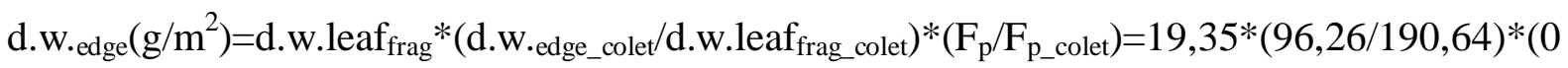
$, 344827586 / 0,210526316)=16,0032581$, and other values can be checked on the above explanation.

The average values of d.w. $\left(\mathrm{g} / \mathrm{m}^{2}\right)$ using the speed, way and direction of the wind in 12,18 and 24 hours per period are presented at the end of Table 3. The estimated drift of litterfall, d.w. (g/m²/year), 2011/2012, by distance, was obtained by the sum of the periods.

Table 3. Tables of frequency at hour 12 for speed, way and direction wind by period, calculate of drift by distance by the proportions, and the end result average of annual drift of litter by the distance (four tables to hours 18 and $24 \mathrm{~h}$ were omitted because they are analogous to those presented). Note: E, SE, S, C do not contribute in litterfall.

\begin{tabular}{|c|c|c|c|c|c|c|c|c|c|c|c|}
\hline $\mathrm{V} 12(\mathrm{~m} / \mathrm{s})$ & $\begin{array}{l}15 / 08_{-} \\
13 / 09_{-} \\
18 / 10\end{array}$ & $16 / 11$ & $14 / 12$ & $16 / 01$ & $14 / 02$ & $15 / 03$ & $15 / 04$ & $14 / 05$ & $12 / 06$ & $15 / 07$ & Total \\
\hline 0 & 1 & & 5 & 6 & 2 & 2 & 5 & 3 & 4 & 3 & 31 \\
\hline 0,5 & 7 & 3 & 5 & 6 & 3 & 4 & 6 & 8 & 13 & 7 & 62 \\
\hline 1 & 11 & 6 & 9 & 5 & 5 & 8 & 3 & 7 & 3 & 7 & 64 \\
\hline 1,5 & 29 & 8 & 2 & 4 & 4 & 4 & 7 & 9 & 7 & 9 & 83 \\
\hline 2,1 & 15 & 2 & 2 & 3 & 6 & 2 & & 1 & 1 & 3 & 35 \\
\hline 2,6 & 9 & 2 & 2 & 2 & 2 & & 1 & 1 & & 2 & 21 \\
\hline 3,1 & 3 & 2 & & 3 & 2 & 4 & 2 & & 1 & 1 & 18 \\
\hline 3,6 & 6 & 3 & 2 & 4 & 2 & 2 & 4 & & & & 23 \\
\hline 4,1 & 6 & 3 & & & 1 & 1 & 2 & & & & 13 \\
\hline 4,6 & 4 & & & & 1 & 3 & 1 & & & 1 & 10 \\
\hline 5,1 & 3 & & & & & & & & & & 3 \\
\hline 5,7 & 1 & & 1 & & 1 & & & & & & 3 \\
\hline Days & 95 & 29 & 28 & 33 & 29 & 30 & 31 & 29 & 29 & 33 & 366 \\
\hline Fragm & 190,64 & 19,35 & 20,78 & 20,19 & 23,99 & 27,92 & 28,99 & 25,12 & 41,08 & 45,62 & 443,68 \\
\hline edge & 96,26 & 8,96 & 6,31 & 6,95 & 11,09 & 12,39 & 11,33 & 5,84 & 8,24 & 13,79 & \\
\hline $5 \mathrm{~m}$ & 27,07 & 2,91 & 2,05 & 2,26 & 3,61 & 4,03 & 3,69 & 1,90 & 2,68 & 4,48 & \\
\hline $10 \mathrm{~m}$ & 16,74 & 1,84 & 1,30 & 1,43 & 2,28 & 2,55 & 2,33 & 1,20 & 1,69 & 2,84 & \\
\hline $15 \mathrm{~m}$ & 17,80 & 1,22 & 0,86 & 0,94 & 1,51 & 1,68 & 1,54 & 0,79 & 1,12 & 1,87 & \\
\hline $20 \mathrm{~m}$ & 13,70 & 0,77 & 0,54 & 0,60 & 0,96 & 1,07 & 0,98 & 0,50 & 0,71 & 1,19 & \\
\hline
\end{tabular}




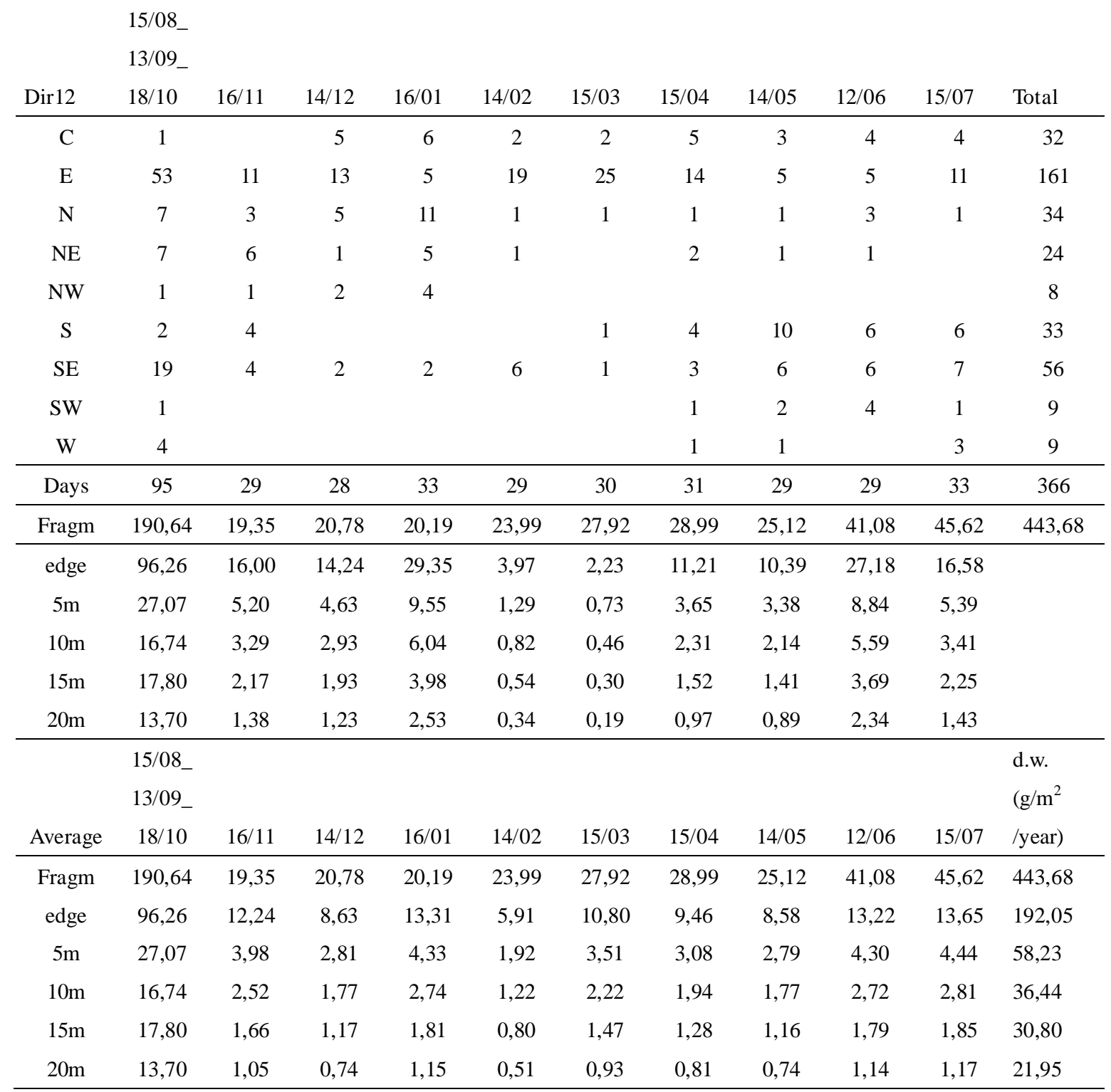

With an estimated d.w. (g/m²/year), the new equation was adjusted (Figure 3), from the distance map of the fragment generated in GIS, and allowed estimating expected annual deposition of forming material of litterfall in the area of study (Figure 4). 


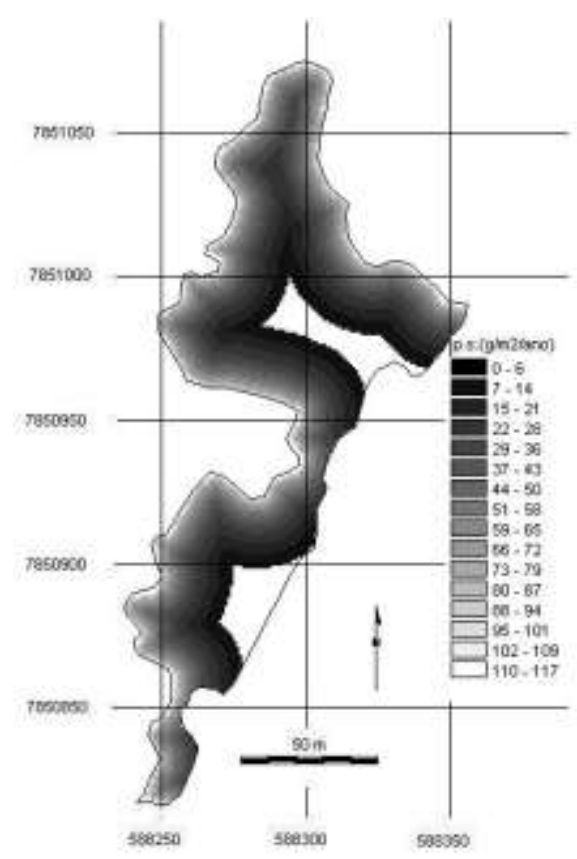

Figure 4. Estimate of expected deposition of the literfall dry weight $\left(\mathrm{g} / \mathrm{m}^{2} / \mathrm{year}\right)$ derived of the vegetation surrounding on period $07 / 15 / 2011$ to $07 / 15 / 2012$, using the equation d.w.

$$
\left(\mathrm{g} / \mathrm{m}^{2} / \text { year }\right)=-33.28 * \ln [\mathrm{d}(\mathrm{m})]+114.99, \mathrm{R} 2=99.35 \%
$$

A limitation of spatial information generated by the function is the uniformity of the amount, because it is considered only the distance of the fragment, and the weighted averages of the direction, way and speed of wind, without spatialization of factors. The model for the variation of deposition rate matching direction, way and speed valid wind by means of friction surfaces, would increase the complexity of the analysis to the result of poor application to this specific area. Thus, the objective was to show the average potential of drift of organic material from forests as a function of distance from the edges, and wind conditions and topographical surfaces will vary according to region and area.

The leaf analysis of macro and micro nutrients from material collected within the fragment is presented in Table 4, and the amount of nutrients deposited in $\mathrm{kg} / \mathrm{ha} / \mathrm{year}$ in the forest interior, as it moves away from the edge, is given in Table 5.

Table 4. Quantity of average nutrients of the litter leafs and their respective variation coefficients.

\begin{tabular}{|c|c|c|c|c|c|c|c|c|c|}
\hline & $\mathrm{N}$ & $\mathrm{P}$ & K & $\mathrm{Ca}$ & $\mathrm{Mg}$ & $\mathrm{Zn}$ & $\mathrm{Fe}$ & $\mathrm{Mn}$ & $\mathrm{Cu}$ \\
\hline & \multicolumn{5}{|c|}{ 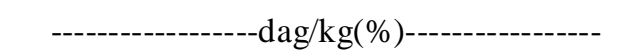 } & \multicolumn{4}{|c|}{-----------------mg/kg(ppm)-------- } \\
\hline Average & 1,38 & 0,09 & 0,76 & 2,05 & 0,29 & 29,38 & 371,19 & 90,71 & 8,86 \\
\hline CV\% & 20,55 & 25,90 & 19,09 & 39,26 & 29,08 & 19,94 & 11,90 & 30,26 & 36,28 \\
\hline
\end{tabular}


Table 5. Nutrients quantity $(\mathrm{kg} / \mathrm{ha} / \mathrm{year})$ as function of distance of fragment.

\begin{tabular}{lrrrrrrrrr}
\hline & \multicolumn{10}{c}{$\mathrm{kg} / \mathrm{h} /$ year } \\
\hline & $\mathrm{N}$ & $\mathrm{P}$ & $\mathrm{K}$ & $\mathrm{Ca}$ & $\mathrm{Mg}$ & $\mathrm{Zn}$ & $\mathrm{Fe}$ & $\mathrm{Mn}$ & $\mathrm{Cu}$ \\
\hline fragm & 61,23 & 3,99 & 33,72 & 90,96 & 12,87 & 0,13 & 1,65 & 0,40 & 0,04 \\
edge & 26,50 & 1,73 & 14,60 & 39,37 & 5,57 & 0,06 & 0,71 & 0,17 & 0,02 \\
$5 \mathrm{~m}$ & 8,04 & 0,52 & 4,43 & 11,94 & 1,69 & 0,02 & 0,22 & 0,05 & 0,01 \\
$10 \mathrm{~m}$ & 5,03 & 0,33 & 2,77 & 7,47 & 1,06 & 0,01 & 0,14 & 0,03 & 0,00 \\
$15 \mathrm{~m}$ & 4,25 & 0,28 & 2,34 & 6,31 & 0,89 & 0,01 & 0,11 & 0,03 & 0,00 \\
$20 \mathrm{~m}$ & 3,03 & 0,20 & 1,67 & 4,50 & 0,64 & 0,01 & 0,08 & 0,02 & 0,00 \\
\hline
\end{tabular}

Having maize crop as reference, common in family farming and broad-spectrum in agricultural activity, using data from export of nutrients at harvest, according to their productivity (Cruz et al., 2008) (Table 6), was calculated the percentage of nutrients that the fragment of semideciduous forest can offer in the replacement of these nutrients, disregarding the factors affecting the mineralization of organic matter.

Table 6. Nutrition requeriments ( $\mathrm{kg} / \mathrm{ha}$ ) of maize crop for productivity of 9.17 and $3.65 \mathrm{t} / \mathrm{ha}$ (Source: Cruz et al., 2008), and percent of reposition of macro and micronutrients offered by semideciduous forest fragment

\begin{tabular}{|c|c|c|c|c|c|c|c|c|c|}
\hline \multicolumn{10}{|c|}{ Requirement of maize to productivity of $9.17 \mathrm{t} / \mathrm{ha}$ (extracted nutrients) } \\
\hline \multicolumn{10}{|c|}{$\mathrm{kg} / \mathrm{ha}$} \\
\hline & $\mathrm{N}$ & $\mathrm{P}$ & $\mathrm{K}$ & $\mathrm{Ca}$ & $\mathrm{Mg}$ & $\mathrm{Zn}$ & $\mathrm{Fe}$ & $\mathrm{Mn}$ & $\mathrm{Cu}$ \\
\hline & 187 & 34 & 143 & 30 & 28 & 0,4 & 2,1 & 0,34 & 0,11 \\
\hline Dist.(m) & \multicolumn{9}{|c|}{$\%$ provided by litterfall } \\
\hline Fragm & 32,7 & 11,7 & 23,6 & 303,2 & 46,0 & 32,6 & 78,4 & 118,4 & 35,7 \\
\hline edge & 14,2 & 5,1 & 10,2 & 131,2 & 19,9 & 14,1 & 33,9 & 51,2 & 15,5 \\
\hline $5 \mathrm{~m}$ & 4,3 & 1,5 & 3,1 & 39,8 & 6,0 & 4,3 & 10,3 & 15,5 & 4,7 \\
\hline $10 \mathrm{~m}$ & 2,7 & 1,0 & 1,9 & 24,9 & 3,8 & 2,7 & 6,4 & 9,7 & 2,9 \\
\hline $15 \mathrm{~m}$ & 2,3 & 0,8 & 1,6 & 21,0 & 3,2 & 2,3 & 5,4 & 8,2 & 2,5 \\
\hline $20 \mathrm{~m}$ & 1,6 & 0,6 & 1,2 & 15,0 & 2,3 & 1,6 & 3,9 & 5,9 & 1,8 \\
\hline \multicolumn{10}{|c|}{ Requirement of maize to productivity of $3,65 \mathrm{t} / \mathrm{ha}$ (extracted nutrients) } \\
\hline \multicolumn{10}{|c|}{$\mathrm{kg} / \mathrm{ha}$} \\
\hline & $\mathrm{N}$ & $\mathrm{P}$ & $\mathrm{K}$ & $\mathrm{Ca}$ & $\mathrm{Mg}$ & $\mathrm{Zn}$ & $\mathrm{Fe}$ & Mn & $\mathrm{Cu}$ \\
\hline & 77 & 9 & 83 & 10 & 10 & 0,16 & 0,84 & 0,14 & 0,04 \\
\hline Dist.(m) & \multicolumn{9}{|c|}{$\%$ provided by litterfall } \\
\hline Fragm. & 79,52 & 44,37 & 40,63 & 909,55 & 128,67 & 81,87 & 197,03 & 297,39 & 89,78 \\
\hline edge & 34,42 & 19,21 & 17,59 & 393,71 & 55,70 & 35,44 & 85,29 & 128,73 & 38,86 \\
\hline $5 \mathrm{~m}$ & 10,44 & 5,82 & 5,33 & 119,37 & 16,89 & 10,74 & 25,86 & 39,03 & 11,78 \\
\hline $10 \mathrm{~m}$ & 6,53 & 3,64 & 3,34 & 74,69 & 10,57 & 6,72 & 16,18 & 24,42 & 7,37 \\
\hline $15 \mathrm{~m}$ & 5,52 & 3,08 & 2,82 & 63,14 & 8,93 & 5,68 & 13,68 & 20,64 & 6,23 \\
\hline $20 \mathrm{~m}$ & 3,93 & 2,19 & 2,01 & 44,99 & 6,36 & 4,05 & 9,75 & 14,71 & 4,44 \\
\hline
\end{tabular}

The results show that the contribution to the soil fertility maintenance in the surroundings of 
forest fragments is not negligible, especially in the management with low input use. For productivities around $3.65 \mathrm{Mg} / \mathrm{ha}$, the replacement of $\mathrm{Ca}$ only by litterfall deposition can reach $45 \%$ at a distance of 20 meters and at 15 meters, the replacement of $20 \%$ of $\mathrm{Mn}$ is possible.

Although the mobility of nutrients has not been measured in this work, is fact that, in most of types of terrain, the forest patch is up, with slopes directed to the cultivated areas through runoff, leaching, carries nutrients to the parts downstream, increasing the efficiency of litter deposited in higher concentrations near the edge of the fragment.

This amount of nutrients deposited at medium and long term will add fertility in soil. This is a benefit to agriculture with low use of inputs, where chemical fertilizers were not applied. It can reduce for the ones who apply based at chemical soil analysis too.

In regions of wavy relief, strong corrugated and rugged have small crops and grassland in the vicinity of environmental reserves at properties. Thus, the nutritional contribution of forest ecosystems for these areas is more in an ecosystem service.

\section{Conclusion}

Neighboring areas of forest ecosystem studied receive contribution of litterfall and their nutrients contained in the organic matter through drift. In this study we verify that the drift of material is not negligible, reached 20 meters away from the edge of the fragment, in the wind conditions, time and location of the studied area, and can provide a reasonable replacement of some nutrients until this distance, considering the agricultural management with low input.

\section{Acknowledgments}

To Project "Recuperação de áreas degradadas voltadas para áreas de preservação permanente, reserva legal, áreas severamente impactadas e de uso alternativo com espécies florestais" ("Recovery of degraded areas oriented to permanent preservation areas, legal reserve, severely impacted areas and alternative use with forest species"), funded by $\mathrm{CNPq}$, coordinated by CNPAB; to Dauler Perona Gomes for donating discarded nets from construction; to Juliana Leite Ribeiro, Marielle Raid and Sabrina Fraga Ferreira, fellows of $\mathrm{CNPq}$ and Fapemig, by their operational support in the installation of this essay and Antonio Claudio da Silva Barros by translate the language in this manuscript.

\section{References}

Andrade, A. G., Tavares, S. R. L., \& Coutinho, H. L. C. (2003). Contribuição da serapilheira para recuperação de áreas degradadas e para manutenção da sustentabilidade de sistemas agroecológicos. Informe Agropecuário, 24(220), 55-63.

Costa, T. C. E. C., Viana, J. H. M., \& Ribeiro, J. L. (2014). Semideciduous Seasonal Forest Production of Leaves and Deciduousness in Function of the Water Balance, LAI, and NDVI. International Journal of Ecology, 1-15. http://dx.doi.org/10.1155/2014/923027

Costanza, R., D’arge, R., De-Groot, R., Farber, S., Grasso, M., Hannon, B., Limburg, K., Naeem, S., O’neil, R., Paruelo, J., Raskin, R., Sutton, P., \& Van Den Belt, J. (1997). The 
value of the world's ecosystem services and natural capital. Ecological Economics. 25 (1). 3-15.

Cruz, J. C., Karam, D., Monteiro, M. A. R., \& Magalhães, P. C. (2008). A cultura do milho. Sete Lagoas: Embrapa Milho e Sorgo. p. 517.

Cunha, G. C., Grendene, L. A., Durlo, M. A., \& Bressan, D. A. (1993). Dinâmica nutricional em floresta estacional decidual com ênfase aos minerais provenientes da deposição da serapilheira. Ciência Florestal, 3(1), 35-64.

De Marco Jr., P., \& Coelho, F. M. (2004). Services performed by the ecosystem: forest remnants influence agricultural cultures pollination and production. Biodiversity and Conservation, 13, 1245-1255.

Duncan, D. H., Dorrough, J., White, M., \& Moxham, C. (2008). Moxham Blowing in the wind? Nutrient enrichment of remnant woodlands in an agricultural landscape. Landscape Ecology, 23.107-119. DOI 10.1007/s10980-007-9160-0

Figueiredo Filho, A., Moraes, G. F., Schaaf, L. B., \& Figueiredo, D. J. (2003). Avaliação estacional da deposição de serapilheira em uma floresta ombrófila mista localizada no sul do Estado do Paraná. Ciência Florestal, 13(1). 11-18.

Giácomo, R. S., Pereira, M. G., \& Machado, D. L. (2012). Aporte e decomposição de serapilheira em áreas de Cerradão e Mata Mesofítica na Estação Ecológica de Pirapitinga-MG. Ciência Florestal, 22(4). 669-680. http://dx.doi.org/10.5902/198050987549

Gomes, J. M., Pereira, M. G., Piña-Rodrigues, F. C. M., Pereira, G. H. A., Gondim, F. R., \& Sil, E. M. R. da. (2010). Aporte de serapilheira e de nutrientes em fragmentos florestais da Mata Atlântica, RJ. Revista Brasileira de Ciências Agrárias, 5(3), 383-391. http://dx.doi.org/10.5039/agraria.v5i3a552

Harmon, M. E., Nadelhoffer, K. J., \& Blair, J. M. (1999). Measuring decomposition, nutrient turnover, and stores in plant litter. In Robertson, G. P., Coleman, D. C., Bledsoe, A. S., \& Sollins, P. (Eds.), Standard soil methods for long-term ecological research (pp. 202-240). New York: Liter.

König, F. G., Brun, E. J., Schumacher, M. V., \& Longhi, S. J. (2002). Devolução de nutrientes via serapilheira em um fragmento de Floresta Estacional Decidual no Município de Santa Maria, RS. Brasil Florestal, $\quad$ (74), http://dx.doi.org/10.1590/S0100-67622002000400005

Losey, J. E., \& Vaughan, M. (2006). The economic value of ecological services provided by insects. BioScience, 56(4). 311-323. http://dx.doi.org/10.1641/0006-3568(2006)56[311:TE

Maman, A. P., Da Silva, C. , Sguarezi, E. M., \& Bleich, M. E. (2007). Produção e acúmulo de serapilheira e decomposição foliar em mata de galeria e cerradão no sudoeste de Mato Grosso. Revista de Ciências Agro-Ambientais, 5(1), 71- 84.

Menezes, C. E. G., Pereira, M. G., Correia, M. E. F., Anjos, L. H. C., Paula, R. R., \& Souza, 
M. E. (2010). Aporte e decomposição da serapilheira e produção de biomassa radicular em florestas com diferentes estágios sucessionais em Pinheiral, RJ. Ciência Florestal., 20(3). 439-452.

Pereira, A. R. (2002). Agrometeorologia: fundamentos e aplicações práticas. Guaíba: Agropecuária. p. 478.

Poggiani, F., \& Schumacher, M. V. (2000). Ciclagem de nutrientes em florestas nativas. In Gonçalves, J.L.M., \& Benedetti, V. Nutrição e fertilização florestal (pp. 287-308). Piracicaba: Instituto de Pesquisas Florestais.

Silva, C. J., Sanches, L., Bleich, M. E., Lobo, F. A., \& Nogueira, J. S. (2007). Produção de serrapilheira no Cerrado e Floresta de Transição Amazônia-Cerrado do Centro-Oeste Brasileiro. Acta Amazônica, $\quad$ 37(4). http://dx.doi.org/10.1590/S0044-59672007000400009

Vital, A. R. T., Guerrini, I. A., Franken, W. K., \& Fonseca, R. C. B. (2004). Produção de serapilheira e ciclagem de nutrientes de uma floresta estacional semidecidual em zona ripária. Revista Árvore, 28(6), 793-800. http://dx.doi.org/10.1590/S0100-67622004000600004

Vogel, H. L. M., Schumacher, M.V., Trüby, P., \& Vuaden, E. (2007). Avaliação da devolução de serapilheira em uma floresta estacional decidual em Itaara, RS, Brasil. Ciência Florestal., 17(3), 187-196.

Zhang, W., \& Swinton, S. M. (2009). Incorporating natural enemies in an economic threshold for dynamically optimal pest management. Ecological Modellin, 220(9/10), 1315-1324. http://dx.doi.org/10.1016/j.ecolmodel.2009.01.027

\section{Copyright Disclaimer}

Copyright for this article is retained by the author(s), with first publication rights granted to the journal.

This is an open-access article distributed under the terms and conditions of the Creative Commons Attribution license (http://creativecommons.org/licenses/by/3.0/). 